CHAPTER 3

\title{
Brave Daughters, Bound Kings: A Female Tradition of Reversal Dālkhā̄
}

The festival and accompanying song tradition of dâlkhāi is consistently listed, along with bhojali and homo, in the category of traditions belonging to unmarried girls within the Phuljhar folklore repertoire. Dälizhāi is more specifically referred to as a "holi [festival of reversal] for unmarried girls." Celebration of the festival was quite consciously suspended in Phuljhar villages in the early I980s, but it lives on in the memory of the folklore community, and its song tradition is still very much alive, having found new performance contexts and thus having developed new meanings. These days dālkhāi gìt, unlike bhojali and homo, are sung outside the festival context by members from the broader folklore community: both Chhattisgarhi and Oriya speakers, married and unmarried men and women, literate and nonliterate. Sung in short fragments as work songs, as singers walk to and from the bazaar, and in joking social exchanges, dâlkhāì gìt are almost always accompanied by snickers or laughter. I was frequently told that these were "bad" (buri, that is, obscene) songs, which implied that they were not fit for my tape recorder. I thought I would find a key to interpreting the nature of these "bad" songs by observing them in their ritual/festival context; what I learned, however, was that it was partially because they had been taken out of this context that they were now labeled as "bad."

I will first examine dālkhā as a festival of reversal traditionally and ritually celebrated by pubescent girls. Much of my understanding of the festival and the significance of its reversals comes from a one-and-a-half-hour sung narrative that I call the Song of Subanbali, which was sung for me by an elderly Oriya widow to whom many villagers referred me. She was known in the village as the person who could always be counted on to know the stories 
behind "why we do things the way we do." Much to the dismay of several other elderly women who had joined me as an audience to the performance of the Song of Subanbali, however, the narrative never mentions the festival or its patron goddesses. When they objected at the end of the performance that, while it was a good story, the singer hadn't told me the story of dialkhāi, the performer only laughed and said, "This is the story." I decided to take seriously her own perception that this narrative would help me unravel the meanings of the festival. Further, I assumed that the festival context in which she placed the narrative was itself a commentary on that narrative. Looking at the two performance traditions in relationship also suggests ways in which ritual and narrative differ and interact.

Although the dialkhāi tradition has been trivialized on one level through the demise of its ritual context, its significance for the girls with whom it is still associated minimalized, the old widow's narrative suggests that it may have served traditionally as a festival marking a pubescent female rite of passage into the "marriageable" category. The connotations of reversal in both the festival and narrative suggest that it may also have been what Judith Okely (I99I) calls a "crack of resistance" against an increasingly dominant discourse (overwhelmingly male and textual) on the "proper" action (dharma) for married Hindu women. That the Phuljhar village headmen have suspended celebration of the festival in recent years suggests that they, too, may understand the tradition to be one not only of reversal but also of resistance.

\section{The Festival Tradition}

As mentioned above, the most common indigenous designation of the dâlkhāi tradition is that it is a "holi for unmarried girls." Holi is a north and central Indian festival celebrated in phägun (February-March) that marks the end of the old year and the beginning of the new. The general mood is one of license and reversal on this day, marked most dramatically by the reversal of social hierarchies when celebrants spray indelible colored water on persons higher on the hierarchy than themselves (called "playing holi"). Low-caste celebrants may spray high castes, and children, their elders; women may spray the men of their households (this female holi play usually being limited to their own courtyards). Lawrence Babb describes the festival in Chhattisgarh as "an occasion upon which ordinary norms and conventions are temporarily overturned. If Hindu culture ordinarily puts a premium on the unassertiveness in women, on holi the reverse is entirely appropriate. Likewise, if Hindu culture ordinarily proscribes open displays of sexuality, on holi sexuality is one of the dominant and most obvious motifs of the day. There is 
a clear sense of reversal in the festival, which perhaps is in no way more vividly exemplified than by the feminine dress some men wear on the day of holi play" (I975:I72). It is in this sense of performatively reversing social position and status that dialkhāi is called a young girls' holī: on this one day, festival participants are permitted a freedom of action and voice contradicting conventional norms and expectations of Chhattisgarhi female behavior.

This indigenous contextualization and designation of the festival, as well as knowing that it was a dying tradition still being performed in only one Phuljhar village, piqued my curiosity, and against the advice of my educated Chhattisgarhi friends, well armored with their dire warnings (which would also be given to any woman entering public space during holi), I attended the dialkhāi festival in the fall of 1980 . Although dälkhāi used to be commonly celebrated all over the Oriya-speaking area of eastern Chhattisgarh and the western hills of Orissa, the year I attended turned out to be the last year it was ritually celebrated in Phuljhar. When I returned to India in 1985 and again in I988 and I993, I could locate no village in which it was still observed.

The dâlkhā festival is celebrated during the fall festival season, which marks the end of the rainy season and the harvest of the rice paddy (the tenth day of the light half of kunvar [September-October]). ${ }^{1}$ Its primary participants are unmarried, pubescent girls from the Oriya Saunra and Sabar ādivāsi (tribal) castes. Other low-caste, nontribal girls sometimes accompany and celebrate with their friends, and infertile married women may participate to a limited degree (by coming out to the open performance field and making offerings to the presiding goddesses but not singing or dancing with the girls) in hopes of gaining the boon of fertility. ${ }^{2}$

The year I observed the festival, a group of ten or twelve àdivāsi girls between the ages of eight and fourteen spent most of the day dancing and singing dâlkhāi git (songs) under a large tree on a clearing a half-mile outside their village, on the edges of what is called "jungle" (uninhabited, unsocialized space). They were accompanied on a village-style oboe (śahnā and drums by a group of three Gara, low-caste male musicians, who also play professionally for weddings. No other adults or males were present, except passersby, the infertile women who came to make special offerings and quickly left, and an elderly Christian woman who had accompanied me to the village. The majority of the consistent audience was made up of a group

${ }^{1}$ This is the same day as dashara a a festival celebrating the victory of the hero god of the Ramayana, Ram, over the demon Ravan and Ram's return to his kingdom after fourteen years of exile. Dasharā is not, however, commonly observed in the Phuljhar villages in which dâlkhā was traditionally celebrated.

${ }^{2}$ See Chapter 2 for a similar participation level of infertile married women in the unmarried girls' bhojali festival. 


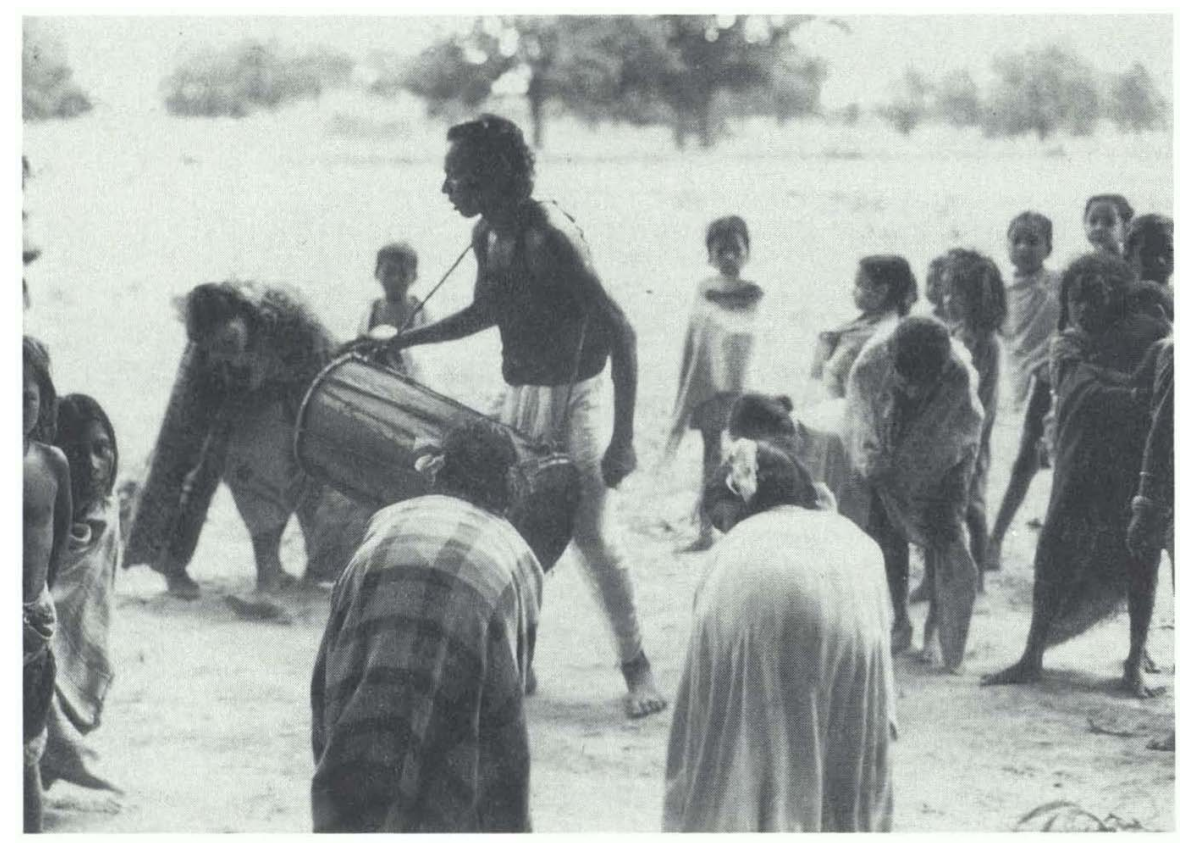

Dālkhāì dance on clearing outside village, Phuljhar.

of twenty or so younger village children, including a few boys. The two oldest dancers, ages thirteen and fourteen, led the dancing and singing,

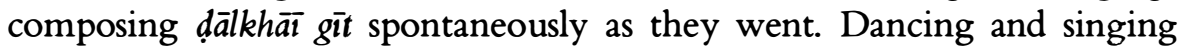
alternated, with the musicians picking up the song melody while the girls danced. The younger dancers did not sing the verses at all, only joining in on the last-line refrain, "ki dālkhāi re."

The girls could not always complete verses they had started, perhaps itself an indication of the dying festival tradition; periodically, they were instructed by the male musicians to sing louder, "with a full voice," or the drummers themselves would take over the singing role. The girls seemed grateful when the Christian woman who had accompanied me, a wonderful performer in her own right who was intimately familiar with Hindu traditions, volunteered to complete a bärahmāsa $\bar{a}$ (twelve-verse poetic form structured around the months of the year) that they were having difficulty filling. The girls completed the following bārahmāsa verses:

Ki d̦älkhāi re!

In the month of mägh, Madhav [Krishna] will come.

I decorated the bed. 
I lit a jeweled lamp and waited.

My eyes keeping vigil, my friend, The night has passed; leave the path.

I'm addicted to the son of Nand.

I can't forget him.

Ki dụlkhāi re!

Ki ḍalkhāī re!

In phägun, color is scarce.

Radha and Madhav will throw color [the holi dyes].

Mixing camphor in the pool of color,

Their companions will throw color.

Jadhu and Gosai, leave the path.

Ki ḍ̛alkhāī re!

Ki ḍălkhāì re!

In mägh, my beloved stayed in a foreign country.

Whom does he love, my dark one,

That he has forgotten me, forgotten me?

Ki dụalkhāi re!

At this point the girls ran out of words, and the older woman picked up the bārahmāsā:

\section{Ki dualkhāī re!}

The month of caitra is cool.

Who will bring to me my Bengali lover?

On her wrists are campā flowers;

On her neck a tulsī garland.

Krishna speaks only one word to Radha

That is beautiful to the heart.

Ki dọalkhāi re!

Then she, too, could not fill in the rest of the months of the poetic form. She told me later that when she sings this dâlkhā bärahmāsa while walking or working in the fields, she never forgets it; but she was not used to singing in the festival context with all the drumming.

Each girl, wearing a skirt and blouse, also had a long shawl-like cloth, or half-sari, draped over her shoulders and back. During the dance segments, the girls held the two ends of this cloth in front of them, bending over and shuffling backward. The cloth suggests the sari a girl begins to wear when she becomes eligible for marriage, traditionally at puberty but these days 
much later if she continues her formal education. (Hence, in the rural areas of Chhattisgarh, the villagers found it highly amusing when I periodically, as a married woman, wore the schoolgirl's dress of salwar-chemise [long tunic and baggy pants] rather than a sari.)

At sundown, after having danced for four to five hours, the dancers and musicians moved inside the village, where the number of both participants and audience members increased. At this time, I left to observe a local Ramayana dramatic performance $(r a \bar{m} l i \bar{l} \bar{a})$ in a distant town that had served as the seat of power for the local maharaja before independence, the Ramayana still being the focus of my research at that time. ${ }^{3}$ But I was told that the singing and dancing on the village main street continued throughout the night. During the course of the entire festival, in and outside the village, coconuts, milk, and flowers were offered to the presiding goddesses, Sarla Devi and Mangla Devi (also call Van Durga, or Durga of the Forest). The goddesses were represented by two kalaś (small brass water vessels with coconuts placed over their openings). The kalas and offerings were immersed, or "cooled," in the village tank early the next morning, marking the end of the festival.

Dälkhär's association with the festival of hoti, its ethos of reversal and inversion, results from the freedom of action and voice given to the dialkhā participants and the temporary suspension of traditional gender hierarchy in the festival context. When the girls are dancing outside the village, they may "attack" any passerby, particularly a man, by hurling dust and abuses at him, surrounding him, if they are able, until he gives them money. An unverifiable oral tradition circulates in this part of Phuljhar that in the late I970s, during the dâlkhāi celebration at a village bordering National Highway No. 6 (hardly more than a single-lane paved road out here in the "jungle"), the festival participants tried to stop truck drivers by stretching a rope across the highway, holding them up until they made payment. But the truck drivers, the story goes, were not from Chhattisgarh and were unfamiliar with dālkhāi and its traditions; they "took advantage" of the girls, and several girls were even said to have run off with them. That it was no longer safe for its female celebrants is one reason frequently cited for the suspension of the festival in recent years.

These days, the most significant reversals are perceived to be those expressed in the dialkhāi gì that accompany the dancing, the buri (bad, obscene)

${ }^{3}$ As it turned out, although I had been continuously assured that the rāmlitā was performed every year in this town, that "it had to be performed," I found out upon arrival that it had been canceled this year because of the year-long mourning period in observance of the death of the current maharaja's mother. 
songs. Several upper-caste women told me that these songs are the reason why a large part of the festival is celebrated outside the village; once the girls return to the village, the songs are said to become less obscene, something I was unable to document. On one occasion, several months after the festival, an acquaintance began to sing some dâlkhä gì for my tape recorder, in her own courtyard, when she was stopped by a woman running in from the village headman's house across the street. The latter told the singer, "You shouldn't be singing burāi (literally, badness) inside the village." The singer then went inside her house and brought out a printed pamphlet (in Oriya script) of dalkhāi git t, presumably less obscene, but she was unable to fit the words to the dialkhāi rāg (melodic structure) that she knew. ${ }^{4}$

Many members of the Phuljhar folklore community attributed the declining state of the festival to the nature of these songs. Several villagers told me that "as our girls are becoming more educated, it is not proper for them to keep singing such songs." One sarpanc (head of a village council) who had banned celebration of dialkhäin in his village told me that the festival was burā, not good for "our educated girls" or for village morale. It is significant that it was the male, non-ädivāsi leaders of the villages with which I am acquainted who made the decision that the festival should be discontinued, not the older village women or the young, would-be festival participants, most of whom are still not educated beyond third or fourth grade.

It was difficult to make good recordings of dālkhāi git during the festival itself because of the loud drumming and the fact that only two girls were actually singing the words of the verses. In spontaneous nonfestival contexts, I often did not have my tape recorder with me when I heard the singing, or the singers would stop as soon as they saw a tape recorder. As a young, white, educated woman who was taking these tapes back to the United States, my interest in the tradition was not seen by educated Chhattisgarhis to be appropriate; nonliterate singers, while often pleased that I knew anything about the tradition at all, were also reluctant to sing for the tape recorder or to discuss the tradition at length when they realized that I was taking it seriously as a tradition to include in my study.

The songs I was able to record and hear both within and outside the festival context contained suggestive, but not explicit, sexual imagery, many of them drawing on the religious tradition of the lovers Radha and Krishna (as in the bārahmāsa cited earlier). I provide examples of verses sung for the tape recorder by the festival participants a week after the festival itself. Mem-

${ }^{4}$ When I realized several months later that I wanted to include the dälkhāi tradition in my study, I returned to this village and courtyard and asked if I could see and copy this pamphlet, but the singer said she could not find it. 
bers of this social group to whom dialkhāi traditionally belongs were the only ones who sang openly for the tape recorder; but even they may have edited their songs in this situation. The first is the same bārahmāsa verse sung by the elderly woman at the festival.

Ki dẹalkhāì re!

The month of caitra is cool.

Who will bring to me my Bengali lover?

On her wrists are campa flowers;

On her neck a tulsi garland.

Krishna speaks only one word to Radha

That is beautiful to the heart.

Ki đọalkhāì re!

Ki ḍalkhāī re!

You're only sixteen years old.

Life's purpose isn't to eat poison!

When the evening turns to night,

Speak with your eyes.

Ki dụalkhāì re!

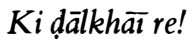

This branch is cut from the auñla branch.

But your short hair isn't attractive.

Short hair needs a pair of flowers;

Short hair needs a bun to look graceful.

Keep your Oriya bun ${ }^{5}$ tied up, my friend.

When you shake it loose, you break my heart.

Ki dụlkhāī re!

Interestingly, the voice of these particular verses is male. He first calls out to the sixteen-year-old girl (older than any of the festival singers themselves, in this case) to realize her sexuality, not to deny it: "Life's purpose isn't to eat poison!" Separation (denial) is against the natural order, causing even the hottest month of the year, caitra, to be cool. In social reality, however, the girls cannot (should not) fully act on their flowering sexuality before marriage, and thus it is bittersweet, likened to the wild forest auñla fruit. In the third verse, the male voice calls for the girl to be a woman, to grow her hair,

${ }^{5}$ Oriya women wear their hair in a regionally identifiable style, with their buns pulled to the side of their head. This type of bun has a specific name, khus $\bar{a}$, as distinguished from a north Indian centered bun, $j \bar{u} r \bar{a}$. 
but then to keep it tied up; for when it is loose (implying uncontrolled, unbounded sexuality), it breaks his heart. ${ }^{6}$

Other verses sung by the elderly woman during the festival itself describe the lovers Radha and Krishna waiting for each other (with another reference to hair, here binding it up in braids); the last verse describes the festival dancing:

Ki d̦âlkhāī re!

Bricks, bricks, bricks,

Sitting on top of the bricks is Mahapura [Krishna].

He keeps eating his breads.

Ki dọalkhā̄i re!

Ki d̦âlkhāī re!

Urā, urā, urā [a grain-storage bin],

Sitting on top of the urā is Radha Rani.

She keeps braiding her hair.

Ki ḍălkhāī re!

Ki dụlkhāī re!

Under the shade of the mahua tree,

The shade of the sarāgi tree [two varieties of jungle trees],

The instruments are playing.

The young girls keep running.

Ki ḍalkhāì re!

To an outside observer, these songs do not seem any more sexually suggestive or explicit than other song traditions which are sung by the same unmarried female of this age and in this area of Chhattisgarh and which are not labeled "bad," such as the bhojali git and homo repartee traditions discussed in Chapter 2. The following homo verse is more explicit about the sexual desire hidden in a woman's hair:

The derhu snake slithers,

Khasā-masā, my friend.

Her face looks old,

But there's desire hidden in her bun [khusā] .

${ }^{6}$ Loosened hair in Indian society has sexual connotations unless in the context of possession or mourning. On reaching puberty, girls in north and middle India must bind their hair in braids and, upon marriage, in a single braid or a bun. In larger cities today, more and more educated women are wearing short hair, but not yet in the villages. 
As important as the actual content of the songs, however, is the community's perception of the songs as "bad," songs that young girls were traditionally permitted to sing in this festival of reversal.

It is probable that dâlkhāi git gained their reputation for being buri when they began to be sung outside the bounds of the festival, no longer restricted by ritual space and time and gender. It is difficult to document when this began to happen, but I was told that it was a recent phenomenon, perhaps coinciding with the demise of the festival. The only implicit performance restriction is that the songs be sung outside the village, although I frequently heard short phrases being sung within the village, and no specific taboo (with consequences) exists for doing so. As the context for the performance of dialkhāi songs has shifted, so have its indigenous genre designation and boundaries. In the last few years, dâlkhāi has begun to be referred to less as a "holi festival for unmarried girls" and more as an "Oriya song," a reference that associates it with the larger Phuljhar folklore community.

\section{The Song of Subanbali}

Several days after observing the festival, I returned to the village in which it had been celebrated to make further inquiries about $d \bar{a} l k h \bar{a} \bar{i}$. I went first to the home of an upper-caste Kolta landowner who was an acquaintance of mine. Although the women of the household assured me that "everyone sings and dances dâlkhāin," they could not give any explanation or etiological narratives for the festival; and, in fact, the girls from this caste do not traditionally participate in dialkhāi. The householders finally directed me to an elderly Saunra-caste ādivāsi widow from their village, Kaushalya Bai, who, they assured me, would be able to tell me "anything I wanted to know." They proceeded to have her called to their courtyard (so much for the fieldworker having control over how such contacts are initiated, although in retrospect, this framing of the contact gave me an indication of the authority the community had vested in the elderly storyteller).

Kaushalya Bai was a sixty-five-year-old widow who was said to have suffered many hardships in her life. She had three grown children. Her son had run away from the village, and no one knew where he lived. The village community considered both daughters to be slightly insane ( pägal); one had died at an early age, leaving two children for her mother to raise, and the other lived in her sasural (home of marriage). Kaushalya Bai was raising her two orphaned grandchildren and made her living by selling puffed rice and peanuts to schoolchildren in the larger neighboring village. Even though Kaushalya Bai thus occupied a somewhat marginal position in the social 
hierarchy of her village, she was, at the same time, highly respected for her knowledge, for being able to explain "why we do things the way we do."

Kaushalya Bai is not a professional performer in the sense that she is hired and gets paid for her performances. In fact, such professional female performers are rare in Chhattisgarh and Phuljhar. ${ }^{7}$ Most of this singer's performances took place in front of small audiences of women; although her narratives may have religious themes, they are not usually performed as part of a larger ritual or festival but as "entertainment" (manoranjan). Because her repertoire of narratives and style of performance are not known to most other women of her caste and age-group, she is in this sense a specialist. Other women may be able to summarize some of the narratives she tells but not perform them. Her sister, living in another village, was similarly well known for her performance abilities and in her younger days was frequently called to sing at dialkhāi celebrations. This sister considered her own unique abilities to be a gift from the goddess, that she may serve the goddess better; she said she had no teacher or guru. Likewise, before beginning to relate segments of various etiological narratives of dialkhāi, Kaushalya Bai credited her own storytelling ability and knowledge to a vision (darśan) given to her by the goddess Parvati and the god Shiva.

The most complete etiological narrative Kaushalya Bai told concerned a pubescent girl who becomes determined, for unspecified reasons, to perform a sacrifice (yagya), an expensive ritual usually communally sponsored by upper castes and controlled by male ritual specialists. Her parents try to persuade her that she is too young to perform such rituals, but she is not deterred. (Note that they do not try to dissuade her because she is a girl.) The yagya she performs is called dalkhāi, during which she and her young friends sing and dance. Since that time, it is said that Oriya girls have celebrated da alkhā once a year. The following is the narrative as reported by Kaushalya Bai:

There was once a daughter named Raila Rani. She was the only daughter of twelve brothers who were all rss i (sages). Her own father was Jagya Rishi, and her mother was Dalmo Bai. She was born only after her mother had completed many austerities [for the birth of a child].

7 The year I was living in Phuljhar (I980-198I), a female professional performer in the area raised high interest and controversy in the communities in which she performed. She was a bahak, a performer who sings and dances at each of the thirteen major Oriya festivals. Her two assistants were male. I heard several people say that in those villages in which a female bāhak performed, there would be crop failure. Nevertheless, she drew large crowds to her performances. More recently, several female candainī and pandvāni professional singers have performed for radio and television, as well as making their own cassette tapes (see Chapters 6 and 7). 
One day, Raila took some golden toys that her parents had given her and went to play near the temple with her friends. She made a house out of mud in which there were twelve rooms. In each room she set up a $p \bar{u} j \bar{a}$ (worship) center for a different deity and began to worship the deities one by one.

As she was playing, Narad Muni, the ascetic of the three worlds, came by and saw Raila playing. She told him she wanted to hold a yagya and asked whether she would be permitted to do so. He assented. Receiving his blessings for the yagya, Raila returned home and asked her parents where she could perform the sacrifice.

Her parents answered her, "You are only twelve years old. How can you know what the gods and goddesses want? Don't perform a yagya yet." Similarly, she asked her grandparents and her brother and sister-in-law, but they, too, scolded her for wanting to perform a yagya at such a young age.

But Raila was not to be deterred. She went to a merchant and purchased from him some poison with which to kill herself. Then, on the shores of the Bandh Ocean, she cried out, "On which bank (ghatt) will I be liberated?" Some baby birds heard her crying and asked their mother the same question on her behalf. She answered, "If she dies on the ghät of Lord Shiva, she will be liberated."

Hearing this, Raila ate the poison on Shiva's ghăt and died. Thereupon, a large fish swallowed her and took her to the underworld (patall lok), where Barun Raja reigned. He scolded the fish for swallowing the young girl and told him to throw her up on the ghät where he had found her.

Barun Raja removed all the poison from Raila's body and asked her why she had swallowed it. She told the king her story. He instructed her to return home where, meanwhile, her relatives and parents had become very worried. When they saw her, they celebrated her return and promised that she could perform a yagya. So, with her young friends, she performed this yagya, the one we call dâlkhāit.

Kaushalya Bai provided another explanation for the festival, one in which the goddess Sarla Devi and her companions were performing a yagya, participating with great "joy and zeal." The young girl Raila Rani saw them while she was bathing in the tank. She returned home and told her parents that she, too, wanted to perform a yagya. With their consent, she proceeded. She and her young friends spent the day dancing and singing. Since then, girls perform dịlkhāi once a year.

In narrating these summaries, Kaushalya Bai was distracted and seemed rushed, not completing sentences or images and frequently meandering from the subject at hand. She was assuming responsibility for transmitting knowledge about the festival, but not responsibility to an audience-in this case one composed of eight to ten girls and women who came and went 
from the courtyard-for an aesthetically pleasing performance. She never, in Dell Hymes's words, "broke through into performance" (I975) ${ }^{8}$ She suggested that she come to my house in the neighboring village (the one in which she sold snacks) in a few weeks to sing for me, in a more relaxed setting, the complete story of dalkhāi. The Song of Subanbali was what she sang; we sat under a large mahuā tree out in the yard of my parents' bungalow; her audience members were three Christian women who worked at a girls' boarding school across the wall (one of whom was the woman who had accompanied me to the festival) and myself.

Beyond the narrative, Kaushalya Bai did not offer any further commentary on the meaning or purpose of the festival ritual. When, after the performance, one of the women complained that dälkhāi had not even been mentioned, Kaushalya Bai implied that the story in this performance mode was complete and enough, shrugging her shoulders and commenting, "That's the story!" While sharing with it a minimal narrative structure (the heroine being the only daughter of twelve brothers, a strong-willed pubescent girl who wants to perform a yagya, thus breaking with social expectations of a girl her age), the Song of Subanbali fully develops themes of reversal and inversion only suggested in the reported narrative. Further, unlike the etiological narratives, the fully performed narrative provides fully developed motivation for the yagya, which in the Song of Subanbali takes the form of a journey undertaken to defeat an evil king.

A large part of Kaushalya Bai's satisfaction with the Song of Subanbali was its performative mode. The aesthetic shaping of the narrative seemed to be, for the performer, inseparable from its content; and she was not satisfied until she had given it such shape. Two factors immediately keyed this storytelling as a semiprofessional performance: the sung recitative style (rather than the spoken prose of summarized "reports" and nonprofessional storytelling, such as folktales) and the initial frame of the invocation or salutation (vandan $\bar{a}$ ) to the presiding deities. The vandan $\bar{a}$ is an indispensable frame of public professional performances in Chhattisgarh, even if the latter's primary purpose is "entertainment," whereas they are absent from privately told folktales or reported narratives such as the etiological ones mentioned above. Kaushalya Bai's vandanā is short, calling on the god Ram and saluting the goddesses of the festival, Sarla and Mangla Devi (note that her couplet referring

\footnotetext{
${ }^{8}$ Hymes makes the distinction between "knowledge what and knowledge how, or, more fully, between assumption of responsibility for knowledge of tradition and assumption of responsibility for performance" (1975:69); italics mine. He calls the latter an "authentic or authoritative performance," and the first, "illustrative, or reportive" (I975:I 8).
} 
to Ram as he whose vehicle is Garuda and whose mother is Kaushalya are verbatim to those sung by the professional storyteller discussed in Chapter s; he also calls on the goddesses Sarla and Mangla, who are associated with speech).

Kaushalya Bai sang in couplets, the second line of which either lexically repeated the first or substituted a phrase from the first with a phrase of equivalent syntactic and semantic structure; the second line expands or reinforces through exact repetition the image of the first line or completes the "sentence," seldom introducing a new image. Several of these couplets were formulas employed throughout the performance to indicate the passage of time or as transitions between the speech of one character and another, such as:

She gave this answer, my Suban.

She gave this reply....

Saying this, the barber [or other character],

Gave this answer....

Hearing this, the barber,

Hearing this, Suban....

After the vandanā, Kaushalya Bai begins the Song of Subanbali in medias res with the juxtaposition of two images: the carefree young girl Suban playing with clay toys and a group of seemingly helpless kings discussing the evil Bandhiya Raja, whom she determines to defeat herself:

At this time, Suban is speaking.

Now, Suban is speaking.

She's holding small clay dishes.

She's holding small bamboo dishes.

She went to play, oh Suban.

She went to play.

She was playing in her playhouse.

She was playing in her playhouse.

There were kings

From the city of Bombay. 
From the kingdoms of Bombay and Cuttack.

From the city of Cuttack.

They spread out their bedding and slept,

Spread it out and slept.

Now they were talking about Bandhiya Raja,

"He is very evil.

He has defeated

Kings from all four directions.

Losing their wealth and riches,

Losing their wealth and riches,

The kings have been imprisoned.

They have been put in jail."

Suban heard this,

And she understood.

The pubescent heroine Suban is the only daughter of king Jagya Rishi and queen Nila Rani and the only female descendant of her father's extended family of twelve brothers. Overhearing the visiting foreign kings talking about the wicked king Bandhiya Raja, who has imprisoned many other kings but whom no king has been able to defeat, Suban immediately resolves to defeat the king herself. Her parents are extremely reluctant to let her go on such a mission; they do not mention her age as a constraining factor, as do the parents of the etiological narratives, but object because she is their only daughter, too precious to risk losing. They finally give their permission, however, and help her get ready for the journey. When Suban requests permission to undertake this journey, she gives no indication as to how she proposes to defeat the evil king. But she does not take an army with her, so it is clear that she does not intend to use traditional martial means for such a defeat.

Suban's decision to set out on the journey also puts into play the reversal of traditional social roles, the central theme of both the narrative and the festival whose "story it tells." A young girl has decided to take upon herself a task rightfully belonging to kings, but one in which they have failed. For the youngest son of a king to succeed where older kings have failed is a common motif in folk narratives worldwide; in the Song of Subanbali, this role would naturally fall to Suban's older brother rather than to the adolescent girl. So, 
here, the reversal is carried one step further: not only does the younger succeed where elders have failed but a woman also succeeds where men have failed.

The second suggestion of reversal is the emphasis placed on the value of the female descendant. Suban's mother objects to the journey, not because she is young or female, but because she is the only female descendant of twelve brothers. She recounts to Suban the tapas (austerities) she had had to perform to receive a daughter. Such asceticism (often through the performance of a vrat, or "vow") is commonly performed for the birth of a first child or, if a daughter has already been born, then for the birth of a son, but rarely for a daughter specifically. Suban's father objects to the journey for the same reason, for fear of losing what he calls "his only wealth."

Suban's older brother is the only person in the narrative who doubts her ability and determination to carry out her mission; and his doubts are openly based on the fact that she is female and perhaps secretly on the fact that she is usurping his role. He tries to hinder Suban by refusing his permission for her to take his wife along as a companion. He tells her:

I won't agree to your request.

I won't let her [Tulsa] go with you.

She's from a woman's caste [ jāti] .

Where will you take her?

A woman's caste is weak.

A woman's caste is weak.

Suban immediately proves him wrong by cursing him with the appearance of boils, burning skin, and finally an unbearable itchiness. As the symptoms begin to appear, Suban's brother not only relents but actually forces his wife on Suban. The rest of the narrative continues to disprove his position on the weakness of a woman's caste.

The gender reversal and expectations for Suban's nontraditional role are further developed in a major subplot at the beginning of the Song of Subanbali. This story is of twelve carpenter brothers who also have only "one wealth" among them, but here, it is a son. They have been commissioned to build a boat for Suban's journey, for which only a single tree in the jungle is

${ }^{9}$ In South Asian ritual contexts, a daughter, particularly as bride, is often called "Lakshmi," the goddess of wealth, but in north and central India, this wealth is transferred to another family upon the daughter's marriage. It is sons who provide the hope for both material wealth and continuity of the lineage. If there is only one daughter among many sons, however, she is usually highly valued in her natal family. 
appropriate (identified for the carpenters by a female vulture). Their axes are dulled after numerous attempts at cutting down the tree, and the carpenters are finally convinced that they must sacrifice their only male descendant before the tree will yield to them. Ultimately, the young boy is ritually sacrificed, without protest, and the tree gives in to their axes. When Suban learns of the boy's sacrifice, she brings him back to life. The singer later told me that Suban was an apsara (celestial nymph) and therefore had such power; however, nowhere else in the narrative is she given this kind of supernatural power.

The subplot is not crucial to narrative progression or continuity, since the boat is not mentioned again in the rest of the song; and Suban travels to Bandhi Desh by land, "crossing and destroying fields," rather than by water. The carpenter's story is, however, integral to Kaushalya Bai's aesthetic shaping of the narrative, drawing Suban's character in a way in which straight description could not. The subplot structurally mirrors and inverts the central plot. Both the carpenters' son and Suban are the "only wealth" of twelve brothers; but the son is the sacrifice, whereas Suban, the daughter, is the sacrificer (after his captivity, Bandhiya Raja fears he will be literally sacrificed; instead, he is brought out to the courtyard to be figuratively sacrificed by means of his marriage to Suban). The carpenter's son is not given a name and has no individual personality; he is passive, seen and not heard, ready to be sacrificed without protest. This image of the passive male, with no "voice," dramatically frames and delineates the determination, strength of will, and active nature of the heroine Suban.

Subanbali borrows male clothing from her maternal grandfather and disguises herself as a young merchant for her adventure. The grandfather does not express hesitation over Suban's ability to undertake the task at hand but worries that, dressed in his clothes, she may act in some impure way (perhaps sexually impure) that will reflect back on him. Suban answers him confidently:

If I do anything impure, cut off my head, Cut out my tongue.

My eyes will burst.

My life breath will leave me.

Suban takes her sister-in-law, Tulsa Rani, as her "wife" and travel companion. When she reaches the kingdom of Bandhiya Raja, the king's barber sees the traveling couple and returns to the king's court to report that he has just seen the most beautiful woman (Tulsa Rani), whom the king must have 
as his wife. The king and barber plot how they can kill the woman's "husband," Subanbali, in order to gain access to his wife. The barber first approaches Subanbali's camp with an offer to shave her, intending to slit her throat in the process (a motif identified by Stith Thompson [1946] in tale type 910C-Think Carefully Before You Begin a Task). But Suban refuses, saying she never lets a stranger shave her. Unthwarted, the barber returns to tell her that the king wants to form a ritual friendship (mahaprasād) with her. Suban tries to resist this suggestion, for she knows the friendship will put her under obligation to the king. But she can think of no excuse, and the friendship is solemnized through the exchange of gifts.

Mahäprasād friendships in Chhattisgarh are formed between members of the same sex but of different castes and are a favorite narrative motif and plotbuilding technique in the folklore of the region. ${ }^{10}$ Rather than using the friendship simply to forward the plot, however, as a less-skilled storyteller might have done, Kaushalya Bai carefully details the preparations for the ritual, through which she further builds the character of the participants and sets up the unequal power relations between the two friends. Suban does more than is required of her in the ritual, whereas Bandhiya Raja carries out only the minimal requirements: she buys the most expensive cloth to exchange with the king (two lengths instead of one), a whole bag full of sweets, five pieces of betelnut, and five coconuts. Bandhiya Raja, on the other hand, buys only one of each required gift. The officiating Brahmin priest's warning, "If friends speak ill of each other / They will turn into tadpoles," takes on special significance given that the king has just tried to kill Suban. Although the heroine is not physically bound as a prisoner in the kingdom of Bandhi Desh, as other kings have been, she is temporarily bound by this mahāprasād friendship.

As Suban predicts, Bandhiya Raja acts quickly to force her to fulfill the obligation of doing whatever is asked by a ritual friend, in this case placing before her three tasks she must complete or be killed: to bring tiger's milk to the king, to jump over a wide pit, and to pick up two gunnysacks full of mustard seeds between evening and dawn. Suban succeeds in completing each of these, but only with the sage advice of the experienced, married Tulsa Rani. Tulsa gives her the precise words with which to speak to the tiger, addressing the tiger as "older mother," calming the hungry animal's wild nature through appeal to her sense of kinship duty and obligation (much the same as those for mahaprasād), and explaining that the milk is necessary for her mother's fast-who could refuse such a request? Tulsa gives

${ }^{10}$ See also the use of mahaprasād as a plot-building technique in the narrative of the kathānī kūhā of Chapter 5 . 
Suban a magic whistle to enable her to jump across the pit; and she calls on her communicative powers with the pigeon kingdom to ask the pigeon king to send five hundred thousand pigeons to help Suban pick up the mustard seeds.

When the test of the tasks fails to defeat his rival, Bandhiya Raja invites Subanbali to play dice with him. She stakes and loses all her possessions in the dicing; in the end, she is forced to put up Tulsa Rani as her stake in the game. At this point Tulsa Rani gives Suban the half-cowrie shell with which Suban's own brother had won Tulsa as bride; and with this auspicious shell, Suban begins a winning streak. She continues to defeat the king until he must put up his own person as stake, and Bandhiya Raja loses that final game as well. Subanbali ties him up like an animal and returns with him to her father's kingdom.

Once in Suban's home kingdom, Bandhiya Raja is ritually bathed and dressed in white; he fears he is being prepared for execution. Instead, when he is brought out of the horse's stable in which he had been imprisoned, he sees he has been prepared not for execution but for his marriage to Subanbali. After the wedding, Suban breaks with the norm by staying in her father's kingdom as his heir (usurping her brother's rightful position), rather than going to live in her in-laws' home (sasurāl).

As a young girl, Suban dons a male disguise to defeat Bandhiya Raja, but she ultimately rules the kingdom as a married woman. The significance of this gender reversal becomes clearer when we look more carefully at the disguise itself and how it is used in this narrative, framed by the festival of dālkhāa. Disguise-concealed identity-is an integral part of many festivals of reversal around the world, as well as literary and folk narrative traditions; it almost always implies a freedom of movement and/or action not traditionally available to the festival participants or narrative character.

Male characters in female disguise often use their new freedom of movement to gain access to women's quarters; female characters most frequently appropriate male disguise for greater mobility in the "outside"/public world. Such is the case of the viraningana a studied by Kathryn Hansen, which are female mythical and historic figures who manifest qualities of virya, or male heroism. Historically, these women have been warrior queens, often taught the martial arts by their fathers, who rule as regents of the kingdom (such as Razia Sultana in the thirteenth century and the Rani of Jhansi in the nineteenth century). The virañingana is identified by male dress and an iconography that portrays her carrying a sword and riding a horse into battle. Such figures reappear in the Hindi folk drama form of nautariki and again in contemporary figures such as the bandit queen Phulan Devi (Hansen I988). The use of male disguise by our heroine fits this model only insofar as it 
enables mobility, but otherwise, Suban's disguise stands in distinct contrast. She finally triumphs over Bandhiya Raja and rules because of her own female qualities, not because of male, royal, or martial disguise.

Disguise not only conceals identity, thereby giving freedom of movement, but also reveals-reveals the social constraints under which the disguised persons normally live. In the case of the Afghan storytellers studied by Margaret Mills, differences in the use of the disguise motif by male and female narrators reveal differences in male and female perceptions of such social constraints and mobility. ${ }^{11}$ Disguise may also reveal aspects of character or society that are generally not visible or openly articulated (see Don Handelman's analysis of Christmas mumming in Newfoundland, I990:155I 59). In their study of festivals of reversal in the West Indies and Nova Scotia, Roger Abrahams and Richard Bauman (1978) suggest that disguise and inversion may reveal an opposition or alternative to "ideal" norms that is continually present at some level, both in tension with and integrated into the dominant ideology of the society.

In my work with Chhattisgarhi and Oriya folk narratives, disguise is a common motif in both male- and female-narrated tales and in each case serves slightly different narrative and thematic functions. In a segment of the Chhattisgarhi oral epic candaini (discussed in Chapter 6) performed by a male Satnami singer of low caste, there is a wonderful scene in which the hero and heroine, on their elopement journey, are traveling through an all-female kingdom. The hero goes into a town to buy pān (betel leaf) and is abducted by the female pan-seller. She dresses him in a sari so that he will not be discovered and then proceeds to try to force him to marry her. Ultimately, the heroine comes to find him and frees him through a dicing game with the pan-seller. The hero's disguise conceals his male identity and thus ensures his safety in a kingdom of women only; but on another level, the disguise is humiliating and concretely reveals his own weakness, his inability to save himself through either traditional male/martial means or by means more frequently associated with women (whose disguise he has taken) and his own nonmartial caste-his wits and ingenuity. In this epic the connotations of the sari, female disguise, are multiple; a female disguise forced on the helpless hero in a narrative context in which the heroine is active, decisive, ingenious, and continually comes to the hero's rescue challenges the dominant (brah-

${ }^{11}$ Mills found that although male narrators tend to avoid active female characters altogether, when they do incorporate them into their narratives, they often cast them in masculine disguise. She speculates that male narrators may see more options for their characters if they are given a male disguise. In contrast, female narrators use the disguise motif much less; their female characters seem to be able to accomplish more as women (particularly with the availability of the veil) than disguised as men (Mills I 985: I95). 
minic) ideological representation of women as needing to be protected by an authoritative male.

In the Song of Subanbali, too, the heroine's male disguise both conceals and reveals. The freedom of movement and action given to her through use of male disguise makes apparent the restrictions normally placed on the movements in the public sphere of a woman in traditional ChhattisgarhiOriya society. Although her gender was restrictive to Suban, however, it was as a daughter that Suban was given reluctant permission by her parents to set forth on her adventure; the male disguise was her own decision. The action and mobility that the disguise allowed Subanbali reveal the courage and ingenuity she possessed as a woman and call into question the necessity for the initial traditional restrictions placed on women that necessitated the disguise.

Suban's disguise is not only one of gender but also a socioeconomic one. She takes the guise of a poor merchant's son, rather than that of a prince; a disguise is not arbitrarily chosen. It accentuates freedom of movement: a merchant has the freedom as well as the necessity to travel widely, even beyond the bounds of his own country. Further, as a merchant, expectations of traditional male options of militarily defeating Bandhiya Raja are eliminated. The disguise raises expectations that Suban's victory will be accomplished through means of trickery, wit, and wisdom, skills often attributed to both traders and women in Indian folktales.

Once Suban reaches the kingdom of Bandhiya Raja, because of the ritual friendship and its obligations, the prerogative for initiating action is no longer hers; this is the only time she is "bound." The king gives her a series of tasks that she must complete or risk losing her life. The traditional tale type is that of a prince who performs certain tasks to win the hand of a princess, tasks usually set forth by the princess's father. Stith Thompson identifies an inverted subtype of this tale, a type that he calls "The Tasks," in which the king covets the hero's wife and sets out tasks to destroy the hero, tasks almost identical to those in our narrative:

(a) The king covets the wife and, on the advice of an evil counselor, usually a barber, assigns the hero tasks in which the hero succeeds through the help of his wife; (b) Quest for a wonder flower; (c) To bring tiger's milk; (d) Tasks requiring great speed: reap a field of grain in one night; build a tank or building in one night, etc., (e) other tasks (Thompson and Roberts I 960:68).

In the Song of Subanbali, the tale type is further complicated through the disguise: a princess, Suban, wins the king, Bandhiya Raja, in marriage through the successful completion of tasks, tasks that have been set forth by 
the same king in his effort to win the hand of Tulsa Rani, the "wife" of Suban. In this radical variation of the tale type, it is also the "wife," Tulsa Rani, who helps the "hero," Subanbali. On the level of disguise, the narrative affirms the wisdom of "wife"; Suban as husband offers few solutions to the successful completion of any of the tasks. On the level of their true identities, Suban as a pubescent daughter is receiving wise counsel from a married woman. Tulsa Rani repeatedly reprimands Suban for disobeying the word of her parents, of tradition:

"You didn't obey the word of your mother.

You didn't obey the word of your father.

To the cities and towns, my Suban,

They forbade you to go.

The word of your grandmother, the word of your grandfather,

The word of your brother.

You didn't listen to the word of anyone.

You didn't listen to the word of anyone.

You came with one mind.

You came with one mind, my Suban.

Now you're being punished.

Now you're being punished. ${ }^{12}$

But then, after saying that she will be blamed if anything happens to Suban,

12 Words very close to these are spoken by the princess in the narrative told by the kathāni $k \bar{u} h \bar{a}$ of Chapter 5 , a princess who has gotten pregnant after hiding her lover in the palace for several months. The immediate context of these lines is a lamentation sung by the princess when she discovers that her husband has abandoned her in the forest and her living baby has been exchanged for a dead one:

Why hasn't Yama [god of death] eaten me?

I didn't obey my mother's words.

I didn't obey my father's words.

I didn't obey my husband's words.

I listened only to myself, lord.

Where did my lord go?

However, as with Subanbali, the princess is ultimately rewarded for her defiance; she is reunited with her husband after many misadventures, and they inherit the kingdoms of both sets of parents. 
Tulsa reassures her that she will find a way to get Suban out of her predicament; she should not worry. Tulsa and the narrative itself both acknowledge the difficulties of and then affirm and reward Suban's defiance against traditional gender roles. The tasks and in a broader sense the journey represent a rite of passage for the young Suban, one through which she acquires new identity and wisdom. She embarks on the journey as a young girl playing with clay toys outside the foreign kings' encampment and returns ready to get married and rule her father's kingdom.

When Bandhiya Raja fails to kill Suban and win Tulsa Rani as his bride through his imposition of tasks, he makes one last effort by proposing to play the dice game with Suban. Dicing is, of course, a strong motif in both the South Asian classical and folk contexts, one that often suggests negotiation, revelation, and/or articulation of gender identities and roles. Examples include the crucial dicing scene in the Mahabharata in which the Pandavas' wife Draupadi is finally put up as stake and humiliated by Duryodhan, the god Shiva dicing with his consort Parvati, ${ }^{13}$ and folk narrative scenes such as the candain $\bar{i}$ dicing described above. In the dicing scene in the Song of Subanbali, the heroine plays the traditional male role in dicing for a woman, in this case the bride her own brother had won through dicing. After losing everything except Tulsa Rani and with the latter's help, Suban begins a winning streak and succeeds in winning the person of Bandhiya Raja himself.

Once Suban defeats Bandhiya Raja, she binds him like an animal, putting a rope through his nose. On reaching her father's kingdom, she has her servants tie him up in the stable and give him only horse feed to eat. He is then bathed and oiled, dressed in white, and brought to the courtyard of the king, Suban's father. Bandhiya Raja fears he has been prepared for execution; however, the courtyard is decorated for a wedding-his wedding to Suban. Bandhiya Raja's fear is not unlike that of many young Chhattisgarhi brides as they leave their natal homes and move into a totally strange household and who frequently articulate their impending marriage as a kind of death.

Chhattisgarhi and Oriya marriage rituals are filled with images of female binding. ${ }^{14}$ An Oriya village bride is brought into the marriage courtyard wearing a fancy wedding sari, but with a traditional handloomed cotton sari given by the bridegroom's family weighing heavily on her shoulders and head. She never lifts her face, nor is it visible, throughout the ceremony. She

${ }^{13}$ See Handelman and Shulman (in press) for a full discussion of dicing in the complex Shiva myth.

${ }^{14}$ See essays in The Powers of Tamil Women (Wadley 1980) by David, Reynolds, and Wadley for examples of female binding and control in both south and north India, particularly their discussions of the south Indian tâli (wedding necklace). 
is literally bound to her husband when the end of her sari is tied to the end of his shoulder cloth, and she follows him in circumambulation around the sacred fire. For a woman in Chhattisgarh, marriage may be marked by five visible signs, the first three having connotations of binding: glass bangles, ankle bracelets, toe rings, vermilion powder in her part (sindūr), and a mark of vermilion on her forehead (bind $\bar{\imath})$. The minimal sign of marriage is the bangles. When a woman's husband dies, she breaks her bangles; she is no longer "bound" through marriage, and her presence is considered to be inauspicious at many rituals. Among those castes that permit the remarriage of widows in Chhattisgarh, the second marriage, solemnized through a simple ritual, is often called cuṛ pahanānā, or "to put on bangles" (Babb 1975:82). Further, a mature woman's hair should always remain bound, except under ritually controlled contexts of mourning and possession, and her sari itself can be seen as binding.

Against these prevalent images of female binding, the reverse image of male binding, particularly of a king, is striking. Bandhiya Raja is ritually bathed, dressed, and bound like a Chhattisgarhi bride. The king's name, "Bandhiya," literally can mean either "one who binds" or "one who is bound." By the end of the narrative, Bandhiya Raja has moved from position of the binder to the bound. The narrative begins with a conversation about a king who has imprisoned other kings. It ends with that same king himself being bound - not by another king but by a young woman, his future bride. The final reversal in the Song of Subanbali occurs after the marriage ceremony, when Suban, rather than her brother, is made heir to her father's kingdom.

\section{Dālkhāi as a Tradition of Initiation}

Let's return now to the inter-"textual" relationship between the festival tradition of dialkhāi and the Song of Subanbali, considering the ritual and narrative as metacommentaries on each other. As Kaushalya Bai perceived when she told the Song of Subanbali as the story of dalkhāi, the narrative imaginatively develops the festival's ethos in a way in which the reported etiological narratives were unable to do. Similarly, without the festival context having been given for the Song of Subanbali, we may well have interpreted it differently.

While both dâlkhāi and the Song of Subanbali identify and contribute to the identity of an independent social category of unmarried girls, unlike homo and bhojali they are also initiatory traditions, rites of passage. The festival participants and narrative heroine begin as pubescent girls whose 
identities shift to brides or potential brides. The narrative itself ends in marriage; through the half-saris worn in the dance, the festival suggests the girls have now reached marriageable age (the age of the participants having increased with the increasing age of marriage for Oriya girls). Themes and images of reversal in both the festival and the narrative traditions also suggest that they serve as rites of passage (I'm thinking specifically of Arnold van Gennep's stages of such rituals: separation, liminality, and reintegration, with the liminal stage often characterized by reversal or inversion). The most complete, dramatic reversals occur when the girls are outside the geographic loci of traditional roles and expectations prescribed for them by the uppercaste, dominant discourse of eastern Chhattisgarh: outside the village (on the boundaries of the jungle) and outside the home kingdom, respectively. The narrative reversal is not circumscribed by the boundaries of the foreign kingdom, however, but is sustained after the heroine returns home. In the Song of Subanbali, although the disguise is limited to the journey, the freedoms and power Suban has acquired using that disguise are not restricted by liminal time and space. When she drops the male disguise, Suban returns to her father's kingdom, now a new bride and female ruler of the land.

Similarly, looking at the festival through the commentary of the narrative, although relaxation or reversal of norms is limited to ritually bound time and place, presumably the young participants, like Suban, are not left unchanged. They have participated in a ritual and imaginative space that has permitted them to express openly and joyfully an alternative to their traditionally prescribed female roles. These traditions transmit an important representation of women, constructed $b y$ women, to a new generation-of brave daughters-a representation that both reflects and continues to inform the constructions of their female world. As Teresa de Lauretis asserts, "The representation of gender is its construction" (I987:33).

As narrative, the Song of Subanbali is able to explore further and make more explicit the implications of the reversals only suggested in the festival ritual tradition of dalkhāi, themes of female freedom, independence, and wisdom. In dialkhāi, while the girls are permitted to step outside their traditional female roles, sing "bad songs," and mock their male superiors, the male-female hierarchy is not explicitly reversed. In the narrative, the hierarchy itself is shaken and brought down. Several male characters find themselves in what might be considered traditional female roles. And Suban is not only granted freedom of movement and action but also, first through disguise and then under her own identity, carries out actions specifically belonging to the male sphere. Unlike the viranganā (female warrior in male disguise) of Indian historical accounts and popular culture, ultimately Suban 
transforms the male role into a female one by casting off her male disguise: this is who she is.

As traditions of reversal and inversion, dâlkhāi and the Song of Subanbali are more than what Max Gluckman (1954) has called a "steam-valve" for, in this case, the fantasies of a young, repressed female population. The festival and narrative reveal, question, and comment on an existing social order largely dominated by a brahminic, male-controlled discourse, a discourse becoming louder and more singular in Phuljhar and Chhattisgarh with increased mass media and literacy, as the region becomes less geographically and culturally isolated. But their potential appears to be more than that of revalidating those very structures; they are "cracks of resistance." As James Fernandez writes, "To point out incongruities is to suggest [the possibility of] their transcendence" (I986:29I). ${ }^{15}$ Although they may not directly challenge existing social and cultural structures, the very performance of an alternative may itself become subversive. Perhaps it is this power of performance that the village male elders recognize when they say, "Our educated girls shouldn't be doing these things," and banned celebration of the festival. ${ }^{16}$

As the performance of the tradition of dâlkhāi is shifting, its songs being usurped by male members of the folklore community and taken outside its ritual bounds, the genre has lost its power and authority for the female community with which it was traditionally associated. It is no longer an acceptable, empowering tradition of initiation for lower- or àdivāsi-caste women but has shifted to reflect a male representation of women, whose sexuality must be bound; it is this representation that identifies the dâlkhāi git as buri (bad or vulgar). At the same time, with the increase of literacy and mass media technology, fewer women are learning and transmitting oral narratives such as the Song of Subanbali, particularly when they are not "crucial" to a particular ritual (as are vrat kathā, stories told at rituals of fasting); Kaushalya Bai said she had taught her song to no one. ${ }^{17}$ But folklore

${ }^{15}$ Reference in Raheja and Gold i 994:105.

${ }^{16}$ Don Handelman (1990:52-53) suggests that "the inversion of a stratified order is still a discourse about that very order of stratification that is inverted. . . . [But] the phenomenon that is inverted posits limits to which the inversion can go. Beyond this, the inversion no longer is true to its foundation-for-form: it is no longer an inversion, but becomes another phenomenon in its own right. If there is the potential for transformation through inversion, then this is likely to happen only when inversion exceeds itself and breaks its connectivity to the phenomenon it inverts-thereby creating a new phenomenon." In this case, the Song of Subanbali seems to have transcended these limits of inversion/reversal, whereas the festival itself only suggested this potential.

${ }^{17} \mathrm{R}$ aheja and Gold write that in northern India, wedding music on cassettes and radio are literally silencing women's wedding songs at the ritual (I 994:I9I). 
76 Gender and Genre in the Folklore of Middle India

has never been static: existing genres shift and even die (as the dialkhāi festival itself), and new contexts and forms continue to emerge (even if not always in the rather "purist" forms that some folklorists try to hang on to). The suā nāc tradition examined in the next chapter suggests the flexibility of folklore genres to adapt to newly emerging contexts and the creativity of their performers to find contexts in which to find voice and assert their identity. 